was compared with the sensation felt after blocking the ulnar nerve or its branches at various levels with procaine.

A block at the elbow, just below the cuff, entirely eliminates the sensation, which must mean that the 12-cm. stretch of nerve lying under the cuff cannot be the origin of all the impulses, or even of a majority of them, as Lewis et al. ${ }^{1}$ suggested. A block of the ulnar nerve branches in the hand, however, which makes the whole or a part of the ulnar skin area anæsthetic, has only the effect of modifying the sensation, the pricks being fewer and less intense, but nevertheless clearly felt in the anæsthetic skin area. This argues against the conclusion of Weddell and Sinclair ${ }^{3}$, since the peripheral endings are, in this case, taking no part in the production of the sensations which are perceived.

The effect of a block half-way between these extremes (that is, mid-forearm) is particularly interesting. The sensation is far less intense than with a block in the hand, although the same skin area is anæsthetized in either case : the pricks are now very few, and although clearly felt as pricks, they are individually less intense than in normal unanæsthetized skin.

These experiments suggest that the intensity and number of the pricks depend on the length of nerve which is recovering from any fixed period of depressed blood-supply, and that no part of a nerve is particularly concerned in generating the impulses which give rise to this form of 'pins and needles'. This probably explains why the pricking of 'pins and needles' is less intense when produced by a cuff at the wrist, and very feeble indeed with a cuff around a finger.

The change in the physico-chemical circumstances governing the excitability of any one nerve fibre, which occurs as the circulation is restored (the removal of a 'substance's), presumably offers to all parts of that fibre the opportunity of firing off impulses, and the chance of some low-threshold point or points becoming rhythmically active should be increased when a greater length of the fibre is exposed to the changed environment.

A fuller account and discussion of this work will be published elsewhere in due course.

Department of Physiology,

G. Gordon

University of Oxford. June 7.

${ }^{1}$ Lewis, T., Pickering, G. W., and Rothschild, P., Heart, 16, 1 (1931). 2 Zotterman, Y., Acta Med. Scand., 80, 185 (1933).

${ }^{3}$ Weddell, G., and Sinclair, D. C., J. Neurol., 10, 26 (1947).

\section{Persistence of D.D.T. in the Soil}

The note by M. S. Smith ${ }^{1}$ concerning the persistence of D.D.T. and 'Gammexane' in soil is in conformity with the results of experiments carried out in Australia on the use of D.D.T. as a control of the scarab Aphodius howitti Hope, the larvæ of which infest pastures on the tablelands of south-easterm Australia.

The species has a simple annual life-cycle, the adult flights occurring in February. D.D.T. was applied to the pasture as a 2 per cent dust in talc at the rate of $3.3 \mathrm{lb}$. of $p p$-isomer D.D.T. per acre in August 1946. At this time the larvæ had almost completed their active feeding stage. No significant mortality resulted from the treatment. However, in the winter of 1947 , the treated areas were completely free from infestation, while adjacent untreated areas were again infested. Indirect evidence suggests that the D.D.T. had its effect on the very young larvæ of the 1947 generation, approximately eight months subsequent to the date of treatment.

On the basis of Smith's results, it may reasonably be expected that the D.D.T. will have persisted and exercised a control of the larvæ of the 1948 generation. At the time of writing, larvæ are as yet too small to enable effective population counts to be made.

The details of this work are being published else. where.

Division of Economic Entomology,

Council for Scientific and Industrial Research, Box 109, City,

Canberra.

June 22.

' Nature, 161, 246 (1948).

\section{Entomological Aspects of 'Swollen Shoot' of Cacao}

THE rapid spread of the deadly 'swollen shoot' disease of cacao first recorded by Steven ${ }^{1}$ in 1936 justly gives cause for alarm. Now believed to be due to a virus transmitted by three species of insects of the family Pseudococcidæ, this malady of unknown origin bids fair to destroy the West African cacao industry. That this is realized by the people of West Africa is evident from the lively public interest in the problem.

It is not, therefore, too soon to pause and take stock of the problem. The good old-fashioned remedy of destroying affected trees and contacts, bearing as it does the stamp of common-sense, has won general support except, perhaps, from the unlettered farmer in whose egocentric view there is only one kind of dead cacao tree.

In this connexion it will be well to keep in mind the entomological aspect of the problem and see how the vectors may be controlled in the primitive conditions under which the crop is produced. One method which does not appear to have received the consideration it merits is that of biological control. In the welter of ideas about resistant varieties, immunization and cutting-out, this elementary aspect seems to have been forgotten. Yet the Pseudococcidæ are in some respects peculiarly amenable to this treatment in the tropics. In West Africa they are not heavily parasitized or preyed upon; and there is in other parts of the world a wide range of parasites and predaceous enemies which could be, possibly usefully, certainly with impunity, introduced into West Africa. I am not unaware of the provocative nature of this proposition. But those who would dismiss it untried should bear in mind the infinitesimal cost of effecting such introductions against the havoc wrought by the disease. No one can say whether the method will succeed. But it is a weapon that has proved itself elsewhere, and, in the present parlous state of the important West African cacao industry, it is one that should be tried without delay.

Department of Agriculture, F. A. SQuire Sierra Leone.

${ }^{1}$ Steven, W. F., Gold Coast Farmer, 7, 122 (1936). 